DOI: 10.5216/hr.v15i2.14133

\title{
A CRÍTICA À RETRODIÇÃO E À NOÇÃO MECANICISTA DE PROGResso: Nietzsche, Benjamin e GuHA
}

\author{
José Costa D’Assunção Barros* \\ jose.assun@globo.com
}

RESUmo: Este artigo objetiva refletir sobre a crítica contemporânea à noção mecanicista de "progresso" e, ainda mais especificamente, sobre o problema metodológico da "retrodição" historiográfica. É discutida inicialmente a questão do finalismo na abordagem teleológica da História, e, na sequência, examina-se a verdadeira questão que envolve este e outros problemas presentes na construção das explicações historiográficas: a retrodição. Depois de esclarecimentos teórico-metodológicos sobre a questão, com exemplos historiográficos, desenvolvemos comentários mais específicos sobre alguns autores que elaboraram uma percepção acerca deste problema, entre os quais Friedrich Nietzsche, Walther Benjamin, Ranajit Guha, Christopher Hill e Josep Fontana.

Palavras-Chave: retrodição, teleologia, historiografia, Nietzsche, Walther Benjamin.

A ideia de "progresso" tem sua história, tal como demonstrou Nisbet (1985). Essa história remonta, para buscarmos as primeiras menções dessa expressão, a autores do século XVII como Leibniz (1697, p.150), e termina por rapidamente se oferecer ao mundo ocidental através da configuração de um novo conceito que já se delineia claramente no século XVIII, particularmente com Immanuel Kant (1798). Desde então se pode dizer que se estabelece definitivamente na história das ideias o conceito de "progresso",

* Professor da Universidade Federal Rural do Rio de Janeiro. Doutor em História pela Universidade Federal Fluminense. 
ao mesmo tempo em que se tornava lugar comum e começava a fazer parte da sensibilidade do homem ocidental este pensamento otimista de que não apenas a ciência impulsiona-se para a frente, na direção do "melhor", mas também de que a própria sociedade progride ou "melhora" progressivamente. Naturalmente que o entusiasmo diante da ideia de progresso conheceu ritmos muito diversificados na história das ideias, e não será este o tema do presente artigo. No século XIX, por exemplo, em pleno florescimento da ciência moderna, poucos afrontariam tal ideia no mundo ocidental. No século XX, quando o desenvolvimento tecnológico torna-se ainda mais acelerado, tal entusiasmo só não cresceu em proporções geométricas porque o novo século traria catástrofes jamais sonhadas, das quais as duas Guerras Mundiais e a explosão da primeira bomba atômica tornaram-se marcos infelizmente inesquecíveis.

Por outro lado, se o conceito de "progresso" tem a sua história, é preciso também registrar o contraponto de uma história da rejeição ao conceito de progresso, desde os seus primeiros desenvolvimentos iluministas e, sobretudo, contra o pano de fundo dos seus desdobramentos no século XIX. Essa é uma história discreta nos seus primórdios, até que as grandes catástrofes do século XX começassem a permitir que a própria ciência fosse questionada no que se refere aos seus reais benefícios para a vida humana, já que a tecnologia começaria desde então a ser utilizada para a destruição em massa da própria vida.

Embora não seja objetivo deste artigo recuperar a história da crítica à noção de progresso, mas apenas refletir sobre um dos seus desdobramentos na elaboração dos modelos historiográficos ocidentais a partir de autores específicos, podemos lembrar que Jean-Jacques Rousseau já se opusera francamente à ideia de progresso no próprio século XVIII, já que, para ele, o que estava em visível progressão era a "desigualdade humana" (ROUSSEAU, 1750). Também Charles Fourier, enxergando para além da já evidente exploração das classes sociais menos favorecidas, chamaria atenção para o fato de que o progresso tecnológico da chamada "Civilização" encobria a exploração crescente do gênero feminino, e ressaltava que, na verdade, o "progresso social" de uma nação deveria ser medido pelo nível de emancipação feminina por esta permitido (FOURIER, 1808). Enquanto este socialista utópico sonhava com um mundo no qual um progresso efetivo pudesse realmente instalar-se, em substituição ao falso progresso da civilização industrial, no campo do pessimismo filosófico surgiria Arthur Schopenhauer (17881860), que em $O$ Mundo como Representação (1819) não veria na história senão a expressão da Vontade através da sua interminável repetição do ciclo 
vicioso da carência, necessidade, desejo e tédio. Por fim, Hermann Lotze (1817-1881), em uma obra de 1864 intitulada Mikrokosmos, iria rejeitar uma concepção oitocentista de progresso que ia deixando atrás de si milhões de excluídos em relação à possibilidade de obter a felicidade, ao mesmo tempo em que, em uma perspectiva distinta, e sem uma preocupação social como aquela esboçada pelos seus antecessores na crítica da ideologia do progresso, o filósofo Friedrich Nietzsche também já começara a opor, à concepção de um desenvolvimento linear e progressivo da história, a perspectiva da descontinuidade, da história que se joga como uma aposta de resultados imprevisíveis, e que não permite assegurar em nenhum momento que a humanidade "caminha em direção ao melhor", tal como haviam proposto Kant (1798), Hegel (1830) ou Augusto Comte (1830-1842).

Essas vozes, ao menos no século XIX, foram relativamente isoladas. De fato, o homem ocidental começara a desenvolver na curva do século XVIII para o século XIX uma noção historiográfica tendencialmente valorizadora da perspectiva do "progresso". Isto é francamente demonstrado por exemplos que poderemos encontrar na produção intelectual da segunda modernidade, tanto com as 'filosofias da história' inauguradas nas últimas décadas do século XVIII, como com as 'teorias da história' que começariam a oferecer um escopo de pretensões científicas à nova historiografia profissional do século XIX. O desdobramento mais notável da ideologia do progresso na historiografia nos é oferecido por uma perspectiva teleológica que é agregada à maior parte das filosofias da história. Se a teleologia histórica já havia sido introduzida por uma história teológica que procurava mostrar que a história de todo o gênero humano confluía para o Juízo Final, com as modernas 'filosofias da história' esta crença no finalismo histórico como que se seculariza.

O nosso objetivo, neste artigo, será verificar como o finalismo historiográfico e a crença em um desenvolvimento progressivo da humanidade, apontando linearmente para um único futuro possível, encontram expressão através de alguns autores relacionados ao Materialismo Histórico, chamando atenção também para as observações pioneiras de Friedrich Nietzsche sobre o tema. Estaremos mais interessados em verificar como estes autores começam a perceber os desdobramentos da ideologia do progresso na historiografia, e como eles realizam a crítica de algumas das mais sutis formas de teleologia que se infiltram no trabalho dos historiadores, mesmo que sem a sua anuência direta. Vamos começar por refletir sobre as implicações do modelo teleológico nas 'filosofias da história', para a partir daí examinar um dos mais intrigantes desdobramentos da perspectiva teleológica no trabalho historiográfico: aquilo que neste artigo denominaremos "retrodição" historiográfica. 
As 'filosofias da história', desde a segunda metade do século XVIII e no decorrer do século XIX, e mesmo mais além, costumavam investir na ideia de que a história humana conduzia-se para algum fim já estabelecido. A partir daí, através de uma espécie de roteiro cujo fim, situado em um futuro menos ou mais longínquo, já se sabia perfeitamente de antemão, os 'filósofos da história procuravam enquadrar todos os eventos e processos conhecidos para que coubessem neste roteiro. $\mathrm{O}$ modelo mais conhecido desse padrão historiográfico foi desenvolvido plenamente por Hegel em sua Filosofia da História (1830), mas também iremos encontrá-lo esboçado por Kant (1798) e por outros autores da segunda metade do século XVIII e da primeira metade do século XIX.

Habitualmente, chamamos a esse modelo historiográfico de "teleológico"; isto porque o filósofo ou historiador fixa um "telos" - isto é, um "fim" - e a partir daí constrói a sua história, já que acredita que o desenvolvimento natural da história humana, ou mesmo da história de um determinado povo, conduz àquele destino, seja por desenvolvimento lógico, dialético, ou por obra de alguma força transcendente ou inerente à própria história humana. A esse modelo, adaptam-se tantos as crenças em uma providência Divina, em um plano secreto da Natureza, ou em uma Razão Universal que se atualiza através da história da humanidade, como também se adaptam as perspectivas de que existe algum tipo de mecanismo preciso e determinista regendo o desenvolvimento da história, ou mesmo de que a realidade é tão lógica que se torna possível prever os seus desenvolvimentos necessários no decurso do tempo. Nesta perspectiva teleológica, sejam quais destas motivações a tiverem alimentado, tudo o que aconteceu no Passado, e o que acontece no Presente, conduzir-se-á necessariamente a este fim último da história, e o que não parece se ajustar a este grande roteiro tende a ser discretamente desprezado ou esquecido. Com o modelo teleológico, ou finalista, o filósofo ou historiador está tão convencido de que a história humana dirige-se ao fim que ele mesmo já conhece de antemão, que seu olhar para os eventos e acontecimentos termina por passar ao largo de tudo aquilo que não se presta àquela explicação histórica que procura abordar a caminhada da humanidade para esse fim.

Embora este modelo tenha começado com as 'filosofias da história' setecentistas - campo de especulações que por definição se presta a discorrer sobre o "sentido da história" - ele chegou a contaminar mesmo algumas das 'teorias da história' que começaram a surgir no século XIX, ou pelo menos isso ocorreu com as contribuições pessoais de alguns historiadores e filósofos ligados a estas teorias. Apesar do rigor de cientificidade de que se revestiram 
as teorias da história a partir do momento em que surge a historiografia científica, e da sistematização metodológica a que se impuseram os novos historiadores profissionais no seu trato com as fontes históricas, é particularmente interessante notar que o traço "finalista", embora se reduza, não desaparece de toda a vasta historiografia que será produzida a partir de então nas diversas alternativas paradigmáticas que se abrem com as 'teorias da história'. De certo modo, não deixa de se enunciar uma perspectiva teleológica da história em certas obras de Marx - fundador do Materialismo Histórico - nos momentos em que se apresenta a ideia de que a humanidade marchava necessariamente e de maneira inevitável para a triunfal implantação do Socialismo como futura forma de organização econômica e política ${ }^{1} \mathrm{O}$ que seria, senão uma leitura também finalista da história humana, a conhecida “Teoria dos Três Estágios" proposta pelo positivismo de Augusto Comte, que preconizava que, em sua caminhada regida pela "ordem" e pelo "progresso", a humanidade passara por três estágios de modo a atingir a sua fase "positiva", para a partir daí adentrar a senda de um progresso social e tecnológico que seria doravante cumulativo e irrefreável, transformando-se ele mesmo nas bases de uma nova "Religião da Humanidade"?

O Materialismo Histórico e o Positivismo são 'teorias da história', assim como o Historicismo ${ }^{3}$. Como paradigmas, eles não pressupõem necessariamente uma leitura teleológica do mundo humano a partir dos sistemas conceituais que movimentam. Assim mesmo, Marx e Comte - fundadores de um e de outro destes paradigmas - de algum modo deixaram-se enredar pela leitura teleológica da história humana. Comte concebe no Curso de Ciência Positiva a marcha da humanidade para o Estado Positivo. Marx, no Manifesto Comunista preconiza a inevitabilidade de uma "sociedade sem classes". O desenvolvimento das forças produtivas sob o capitalismo, neste caso, preparava as condições e contradições que levariam a uma revolução proletária e ao fim de uma história calcada no antagonismo de classes. No "Prefácio" de Contribuição para a Crítica da Economia Política, Marx chega a afirmar que a verdadeira história somente começaria nesse momento, pois com a "sociedade burguesa" termina a "pré-história da sociedade humana" (MARX, 1984-b, p.234).

$\mathrm{O}$ "progresso", no século $\mathrm{XX}$, era uma noção que poucos intelectuais pensaram em questionar; e a tendência a pensar que o progresso conduziria a um fim já estabelecido, que quase poderia ser previsto ou intuído, era uma tentação bastante forte para qualquer pensador do social. Poucos já haviam dado a perceber, e Rousseau fora um pioneiro com o seu ensaio sobre a Origem da Desigualdade Humana (1750), que o progresso tecnológico e o 
progresso da justiça social não andam necessariamente superpostos. Outros também se aventuraram em opor suas inquietações e críticas diante da corrente de otimismo em relação ao progresso da humanidade, mas são inegavelmente poucos estes pensadores quando os comparamos com a tendência geral dominante.

Nosso objetivo nas próximas linhas será o de discorrer não tanto sobre a rejeição da perspectiva finalista na história da historiografia, mas sim sobre um problema teórico-metodológico que pode afetar a pesquisa histórica a todo momento. Trata-se de um problema bastante semelhante ao da "leitura teleológica da história”. Na verdade, pode-se mesmo dizer que a leitura teleológica da história é um caso particular deste problema mais amplo, que se insinua por vezes de maneira imperceptível no fazer historiográfico, e não foi senão por isto que esboçamos este pequeno preâmbulo com vistas a esclarecer os aspectos que envolvem a perspectiva teleológica da história. Daremos a perceber em seguida que o filósofo alemão Friedrich Nietzsche, que ousaria criticar a nova historiografia científica no próprio "século da história" , foi talvez um dos primeiros a chamar atenção para este aspecto do qual diversos historiadores iriam se tornar apenas mais conscientes a partir do século XX: o fenômeno da "retrodição". Este fenômeno típico da construção historiográfica não é analisado por Nietzsche com esta denominação, mais moderna; mas de todo modo esse autor toca de maneira surpreendentemente perspicaz nessa questão fundamental que pode afetar efetivamente o fazer historiográfico. A retrodição, conforme veremos, não deixa de ser uma espécie de finalismo, de "teleologia" que fixa um fim para a história e que insiste em submeter todos os processos e acontecimentos ao telos idealizado - embora se trate, obviamente, de um finalismo mais sutil, e que por isso pode quase passar despercebido ${ }^{5}$.

Procuremos, antes de mais nada, uma primeira aproximação do problema em questão. O moderno conceito de "retrodição" foi criado para iluminar uma peculiar situação que se produz em função das especificidades do trabalho do historiador. Trata-se, se pudermos empregar esta imagem, de uma espécie de "profecia" ao avesso. Na "profecia", o profeta faz previsões relacionadas a um futuro que ainda não conhece - o seu futuro. O historiador, por outro lado, acha-se em uma posição peculiar quando analisa um período histórico qualquer. Através das fontes e de seu conhecimento prévio sobre a história de vários períodos, ele está na singular posição que o permite analisar um Passado do qual já conhece o Futuro. Isto não apenas porque ele mesmo, historiador, pode se referir ao seu próprio Presente como um futuro, por vezes distante, em relação aos acontecimentos e processos 
que está analisando. Na verdade, o historiador também tem conhecimento ou pensa ter conhecimento de todos (ou de um bom número) dos futuros intermediários de um certo passado em relação à sua própria época de historiador: ele conhece, por exemplo, o futuro próximo de um determinado Passado que está analisando, pois este futuro é também seu passado; ele pode lê-lo através das fontes. Esta discussão foi bem desenvolvida na obra de Koselleck, com o conjunto de ensaios articulados que recebeu o título de Passado Futuro (1979).

Para dar um exemplo inicial, um historiador que se proponha a examinar os primórdios dos movimentos que conduziram à Revolução Francesa já conhece, de antemão, todas as etapas deste processo, a tomada da Bastilha, a proclamação da República, o Terror atingindo sucessivamente realistas, girondinos e jacobinos, a repressão dos movimentos mais à esquerda, a entrega do poder ao Diretório, a posterior concentração do poder nas mãos de Napoleão, as guerras por eles promovidas, seus sucessos, seu fracasso, o Waterloo, o Congresso de Viena, a Restauração. Deste modo, aqueles primórdios revolucionários, dos quais partíramos, podem ser pensados, na verdade equivocadamente, como algo que conduziria necessariamente a cada uma destas etapas que se verificaram de maneira efetiva na história. Uma coisa se encadeia na outra, como se a Revolução e seus desdobramentos já pudessem ser previstos ao se falar dos primórdios revolucionários (e esta expressão "primórdios revolucionários" já é de si mesma uma retrodição).

O caso mais banal de retrodição, talvez o mais evidente, é aquele que estabelece como um ponto de chegada o próprio presente do historiador, e a partir daí avalia os demais momentos como elos que o produzem linearmente, indo buscar, no limite, as origens do presente que se tem por bem conhecido e quase como um contexto dado. Tal procedimento deixa de perceber essencialmente duas coisas: (1) Em primeiro lugar todo Presente, inclusive o nosso, deve ser sempre problematizado. De fato, o nosso presente - isto é, o presente do historiador - não pode ser tomado como um dado imóvel e tampouco como um contexto passível de ser lido consensualmente por todos: ele é produto de leituras diversas que se estabelecem a partir de cada um dos seres humanos que vivem nele. (2) Em segundo lugar, qualquer ponto no Passado também deve ser sempre problematizado, e nenhum momento no passado faz parte de uma cadeia linear que estaria destinada a se conduzir de forma inelutável ao nosso Presente ou ao que pensamos ser o nosso Presente. Com a retrodição, que não atenta para estes aspectos, a história passa a se assemelhar a uma estreita e sólida "rua de mão única", e não a um mar de possibilidades cujas águas se projetam para o futuro.

José Costa D’Assunção Barros. A Crítica À Retrodição e à Noção Mecanicista de Progresso: Nietzsche, Benjamin e Guha 
Em vista do que foi dito, se queremos nos tornar navegantes que se arriscam neste vasto e complexo oceano da história, devemos evitar a ideia um tanto vulgar de que a função do historiador é encontrar definitivamente a "origem" de seu mundo histórico, na verdade da pequena ilha onde se ergueu uma singela cabana. Marc Bloch, aprofundando uma observação que já havia sido feita por François Simiand no início do século XX (1903), iria criticar precisamente essa pretensão que ele denomina "mito das origens". Esta antiga pretensão de encontrar as origens ou a 'causa primeira' de uma cadeia de acontecimentos pode ser entrevista no famoso manual escrito por Langlois e Seignobos, escrito em fins do século XIX: "A história nos faz compreender o presente, explicando-nos onde for possível, as origens do atual estado das coisas" (1944, p.75) ${ }^{6}$.

Uma ressalva deve ser feita antes de prosseguirmos. O vício da retrodição, e a busca do "mito das origens", nada têm a ver com o fato de os historiadores compreenderem, e cada vez mais nos dias de hoje, que toda História é produzida de um Presente; também não têm relação com a ideia de que se pode revitalizar o Presente a partir de novos olhares sobre o Passado, como propõe Walter Benjamin em texto que já discutiremos (1940). O vício da retrodição está ligado à ideia de que existe uma cadeia linear e única de acontecimentos em uma estreita e necessária relação de causa/efeito que pode ser recuperada pelo historiador. Por outro lado, é sempre bom lembrar que o "mito de origens", nesta sua versão que o direciona para o Presente, é apenas um dos casos particulares da retrodição. O mesmo procedimento que gera uma retrodição em relação ao tempo presente pode ser aplicado para qualquer ponto do Passado, ou seja, para qualquer "Presente" anterior, e são estas situações mais sofisticadas que nos interessarão neste momento, considerando ainda que, embora elas nem sempre sejam percebidas facilmente, mesmo pelos historiadores, elas foram percebidas com especial clareza por Nietzsche, este filósofo de cuja crítica à historiografia nos ocuparemos nas próximas linhas, e posteriormente por Walter Benjamin, filósofo marxista que escreve nas primeiras décadas do século XX (1940).

Pensemos a partir de um exemplo. Suponhamos que estamos trabalhando no âmbito daquela modalidade historiográfica que hoje é denominada "História Intelectual", e que desejamos examinar a figura histórica do célebre doutor Philippe Pinel (1745-1826) - médico francês que viveu no período da Revolução Francesa. Poderíamos começar por tentar construir uma história para compreender as ideias de Pinel, autor do primeiro esforço conhecido de elaboração de uma classificação para as diversas formas de loucura, dividindoas em "manias", "melancolias", "demências", "idiotias" (PINEL, 1801). Gradu- 
almente surgiriam, depois de Pinel, outros sistemas classificatórios, alguns bem mais complexos, de modo que ao médico francês é atribuído muito habitualmente um papel importante nesta história das ideias e das práticas clínicas. Pinel pode ser mesmo pintado como um ator histórico fundador da Psiquiatria. Frequentemente a Psiquiatria, através dos historiadores desse campo disciplinar, reivindica para si a figura fundacional de Pinel.

Deixemos por um instante a História Intelectual, e passemos à modalidade da Biografia - outro gênero historiográfico que é frequentemente elaborado por historiadores, mas também por intelectuais de tipos diversos. Para traçar a biografia deste personagem ilustre, talvez fosse oportuno pesquisarmos, em algum momento, os anos de sua formação, o seu interesse pelos excluídos que eram situados no campo da "desrazão", e por fim a sua ascensão profissional até assumir a função de diretor do manicômio de Bicêtre, nos arredores de Paris. No calor e no espírito dos acontecimentos revolucionários e pós-revolucionários, veremos que Pinel consegue autorização para libertar, das correntes de ferro que os aprisionavam, certos indivíduos considerados loucos. Nossa biografia avança por este caminho, mas poderiam ter sido escolhidos outros.

Abandonemos neste momento o campo da Biografia, mas sem retornar à História Intelectual, e situemo-nos agora na própria perspectiva de uma História da Psiquiatria. Já fizemos notar que, neste domínio temático da história, frequentemente os historiadores desse campo disciplinar fazem suas narrativas remontarem a Pinel, já que este foi um dos primeiros autores a tentarem elaborar uma classificação que desse conta dos excluídos da desrazão (evitemos, ainda, chamá-los de loucos, o que já nos introduziria no campo mais problematizado da História da Loucura). Para escrever a História da Psiquiatria, de que ponto partiremos? Ao escolher historiar a instituição deste campo de saber que é a Psiquiatria, somos tentados a percorrer em pontilhado uma certa narrativa com vistas a esclarecer a origem e o desenvolvimento subseqüente desse campo disciplinar que começa por separar os "loucos" da sociedade, e logo depois por separar estes mesmos loucos uns dos outros através de sistemas de classificação que parecem culminar, no decurso de um longo processo de formação deste campo de saber, com a tábua de classificação hoje predominantemente aceita pelas associações psiquiátricas internacionais. É lugar bastante comum que o historiador da Psiquiatria comece por falar sobre as origens deste campo disciplinar, e que tenha ideia de buscar esta origem neste personagem que foi Philippe Pinel. O papel de "fundador" de um campo de saber como este lhe cai bem - é o que muito habitualmente se pensa.

José Costa D’Assunção Barros. A Crítica À Retrodição e à Noção Mecanicista de Progresso: Nietzsche, Benjamin e Guha 
Mas suponhamos que o nosso historiador é ele mesmo um médico ligado ao estudo e tratamento de alienados mentais, mas que seja mais particularmente ligado ao chamado movimento da "Anti-Psiquiatria". Sua História, agora, talvez seja construída de outra forma. Pode-se mesmo dizer que a sua História será obrigatoriamente outra, bem distinta da História que é habitualmente elaborada pelos psiquiatras favoráveis ao tratamento de "alienados mentais" através da internação. Contudo, mesmo a história da Anti-Psiquiatria poderá também incorporar a figura do Doutor Pinel, e de um ponto de vista bastante positivo. Vamos lembrar que, quando escrevíamos a sua biografia, lidamos com os fatos relacionados à decisão de Pinel de libertar de suas correntes os excluídos da desrazão, aqueles homens que se encontravam acorrentados no manicômio de Bicêtre. Se nos encontramos prestes a escrever uma "História do Movimento da Anti-Psiquiatria", a figura do Doutor Pinel encontrará aí o seu lugar, até mesmo um lugar fundacional. Afinal, seu gesto de libertar das correntes de ferro os excluídos da desrazão não deixa de ser um gesto radicalmente anti-psiquiátrico, ao menos do ponto de vista dos teóricos que militam nesta perspectiva teórica. Pinel aparece, então, como o emblemático fundador da Anti-Psiquiatria. Mas como? Quando estávamos dispostos a escrever a história da Psiquiatria, Pinel - autor de uma das primeiras tábuas de classificação que iriam ajudar a consolidar um novo campo de saber que hoje é compreendido como Psiquiatria - aparecera como fundador desta prática. Agora, aparece como fundador de outra?

O pequeno conjunto de considerações e centelhas factuais que entretecemos em torno da figura de Philippe Pinel, e de seus relatos possíveis, constitui um bom exemplo da "retrodição historiográfica". Conforme se situe o historiador diante de certa questão, é muito comum que ele reconstrua a história de uma determinada maneira. Vale lembrar que, quando existe certa riqueza de possibilidades narrativas envolvidas, o jogo de relatos historiográficos possíveis sobre um mesmo tema mostra-se um universo bastante vivo. Por outro lado, quando toda uma cultura pensa de maneira mais ou menos homogênea a respeito de uma questão específica, com um mínimo de variações, a retrodição pode produzir resultados empobrecedores. A riqueza possível de narrativas historiográficas corre o risco, em certos casos, de se reduzir a uma única linha, aniquilando todas as possibilidades de passados anteriores. Se no exemplo atrás desenvolvido pudemos fazer que aparecessem alguns relatos distintos sobre a figura de um mesmo personagem histórico - no caso o médico francês Philippe Pinel do final do século XVIII - isto se deu precisamente porque pudemos contrapor a perspectiva tradicional da Psiquiatria e a perspectiva teórica do movimento da Anti-Psiquiatria. Duas 
leituras distintas acerca das formas de tratamento ideais para determinado conjunto de patologias conduziram a relatos diferenciados.

A contraposição de perspectivas teóricas, de alguma maneira, é quase sempre enriquecedora para fazer emergir novas possibilidades de composições historiográficas. Já a história estereotipada de certos processos e acontecimentos, que todos passam a reproduzir acriticamente, e mais ainda as leituras históricas impostas dogmaticamente, às vezes com a força dos governos ditatoriais ou do poder econômico, podem contribuir para soterrar tudo aquilo que não se adéqua ao relato pretendido, oficializado, canonizado. Ao historiador, ao verdadeiro historiador que se recusa a glosar a historiografia que lhe é imposta de cima, cabe se tornar arqueólogo dos elementos esquecidos, bem como se fazer reconstrutor de outras narrativas possíveis. Ele deve "nadar contra a corrente" da historiografia oficial que emana dos grandes governos e interesses institucionais e que, servindo a estes interesses, deixa de servir à Vida. Nas palavras de Walter Benjamin, o historiador deve "escovar a história a contrapelo" (BENJAMIN, tese n. 7, 2008, p. 225).

A possibilidade da "retrodição", tal como procuramos esclarecer através dos exemplos evocados, leva o historiador à possibilidade de analisar um determinado Passado já conhecendo o que aconteceu depois (o que aconteceu imediatamente depois, por exemplo). A "retrodição" consistirá, aqui, em uma "predição para trás". Alguns teóricos e historiadores sugerem que, mal administrada, a "retrodição" pode vir a constituir-se em um fator de empobrecimento de perspectivas, em uma verdadeira "armadilha historiográfica”. Julio Aróstegui, no capítulo "A Análise da Temporalidade” de seu livro A Pesquisa Histórica (1995), sugere que "o historiador deve explicar as situações históricas como se não conhecesse o seu futuro” (2006, p.354) ${ }^{7}$.

Em um dos Fragmentos Póstumos escritos por Nietzsche entre os outonos de 1884 e 1885, e em outras passagens que poderiam ser citadas, encontraremos - possivelmente pela primeira vez - a discussão deste problema:

[...] todos os órgãos de animais exerceram originariamente outras funções diferentes daquelas que nos fizeram chamá-las de 'órgãos' e em geral cada coisa teve uma gênese diferente daquela que a sua utilização final deixa supor. Mostrar o que é nada esclarece ainda sobre a sua gênese, e a história de uma gênese nada ensina a respeito dela, mas somente o que existe agora. Os historiadores de todo tipo se enganam quase todos neste ponto: pois eles partem do dado e olham para trás. Mas o dado é algo de novo e do qual não se pode absolutamente tirar conclusão: nenhum químico poderia predizer o que resultaria da síntese de dois elementos, se ele já não o soubesse (NIETZSCHE, 2005, p. 306). 
Muito antes de Marc Bloch (1942) discutir a questão do "mito das origens", e, antes deste último, François Simiand ter falado no "mito das origens" como um dos "ídolos" da "tribo dos historiadores" (SIMIAND, 1903), já em pleno século XIX Nietzsche vinha chamando atenção para esta questão, que mais tarde Foucault iria retomar na sua busca de um método genealógico que contornasse essa obsessão historiográfica pelas origens (voltaremos a esta questão). O filósofo alemão já percebia, por exemplo, que um erro historiográfico comum ocorria quando, ao identificar um certo elemento que fazia parte de um conjunto interrelacionável, ou ao identificar a utilidade ou finalidade que certos aspectos vieram a adquirir depois, não raro os historiadores incorriam no erro de presumir que o elemento que assume posteriormente certo papel em relação a um outro era a sua própria origem. Em um dos Fragmentos Póstumos de Nietzsche, datável da primavera de 1874, encontraremos um exemplo:

Em todas as questões que levam à origem dos costumes, dos direitos e da moral, devemos também nos impedir de considerar a utilidade que um certo costume ou crença moral apresenta, seja para a comunidade ou para um indivíduo, como sendo também a razão do seu surgimento: como fazem os ingênuos da pesquisa histórica. Pois a própria utilidade é algo móvel, cambiante; sempre se reintroduz um sentido novo nas formas antigas e o sentido 'que chega mais rapidamente ao espírito' de uma instituição é frequentemente aquele que lhe fora concedido mais tardiamente. Ocorre aqui como nos 'órgãos' do mundo orgânico: aqui também os ingênuos acreditam que o olho nasceu por causa da visão (NIETZSCHE, 2005, p. 305).

As ilusões historiográficas produzidas pela retrodição passariam a se constituir em um dos temas percorridos pelas discussões historiográficas das últimas décadas do século XX. Podemos ter uma ideia, aqui, da acuidade de Nietzsche ao perceber pioneiramente esta sutil questão que pode enredar o trabalho do historiador, ainda no século XIX.

Autores contemporâneos os mais diversos, desde o filósofo Walter Benjamin (1940), na primeira metade do século XX, até os historiadores Josep Fontana (2000) e Ranajit Guha (1993), nos anos mais recentes, começaram a se dar cada vez mais conta deste problema que havia sido diagnosticado por Nietzsche. Para além das críticas que se tornaram clássicas contra as modalidades de finalismo que apontam para o futuro (o velho modelo das 'filosofias da história' e outros tipos de meta-narrativas), estes autores estão de fato se referindo a uma teleologia mais sutil, que reconstrói a história de uma maneira igualmente linear, mas que aponta para o nosso próprio 
Presente como ponto de chegada. Quando está sob esta perspectiva e não a reelabora criticamente, o que um historiador faz é selecionar os seus objetos e fatos históricos apenas levando em conta uma certa história cujo final ele já conhece, e que se situa no seu Presente.

Em outras palavras, o historiador "retroditor" escolhe tudo aquilo que se encaixa no aparente desenvolvimento histórico linear que teria resultado em seu (nosso) mundo Presente, e despreza tudo o mais: as experiências humanas não concluídas, as grandes e pequenas descontinuidades, as hesitações e tateamentos, os desenvolvimentos interrompidos, os atalhos históricos não percorridos - enfim, o historiador, ao trabalhar com esse tipo de 'teleologia reversa', termina por desprezar todo um material histórico de grande riqueza, tal como já havia vaticinado Nietzsche - um material histórico que poderia trazer contribuições para a reinvenção do nosso próprio presente, mas que é literalmente condenado ao esquecimento através deste sutil processo que se inscreve simultaneamente em nosso padrão historiográfico e em nossos recursos de escrita.

Alguns esclarecimentos se fazem necessários para que possamos compreender todos os aspectos implicados na intrincada questão da retrodição historiográfica. O problema não é, obviamente, escrever a História amparado em um certo presente, pois isto é inevitável - como já sustentara Nietzsche, e tal como sustentariam os historicistas e materialistas históricos do século XX. Mais do que inevitável, este escrever a história de um determinado ponto de vista temporal e historiográfico pode se configurar mesmo em um aspecto enriquecedor para a História. O problema, na verdade, é escrever essa história a-criticamente, não apenas esquecendo que se está escrevendo a história a partir de um presente, mas também se deixando enredar pela ideia de que este presente teria sido o único presente possível, e que o passado que ele parece trazer atrás de si a partir da historiografia retroditora é o único passado possível: um passado linear, único, que conduz mecanicamente a este presente, e que cumpre apenas registrar desapaixonadamente.

Será útil retomar as considerações de Walter Benjamin (1892-1940), um filósofo que foi mesmo além de Nietzsche nesta reflexão sobre a prática da "retrodição", além de desenvolver uma crítica igualmente mordaz contra a ideia de progresso na modernidade ocidental ${ }^{8}$. O principal escrito de Walter Benjamin sobre a História - no qual ele aborda tanto a questão da crítica à noção mecanicista de progresso histórico como o problema metodológico da "retrodição historiográfica", embora sem denominá-la assim - foi o manuscrito intitulado Teses sobre o Conceito de História (1940) ${ }^{9}$. A elaboração deste texto no último ano de sua vida, quando estava sob perseguição das 
autoridades nazistas, apresentou-se ao filósofo alemão como oportunidade exemplar para criticar a prática historiográfica de sua época, mas também veio a se constituir em um grito de alerta que buscou submeter a uma implacável crítica não apenas o pensamento liberal da primeira metade do século XX, como também as ações das esquerdas de sua época - sejam as das correntes que aderiram às ações e propostas stalinistas, como também os encaminhamentos que já vinham sendo propostos pela social-democracia alemã desde o início do século ${ }^{10}$.

A questão historiográfica, neste momento, é a que mais nos interessa. Benjamin considera, à partida, que há algo de sombriamente equivocado em considerarmos que vivemos o único presente possível - este presente que surge mecanicamente e linearmente de um passado, que por sua vez é redesenhado ele mesmo como o único passado possível, e sob um quadro fatalista no qual as três instâncias da temporalidade (o passado, o presente e o futuro) estariam enredadas por um progresso inevitável, naturalizado, no qual podemos sempre confiar cegamente, no sentido de que trará um mundo sempre melhor (na verdade não apenas um mundo melhor, mas de fato "o único mundo possível").

A crítica à ideia de Progresso, em Benjamin, é visceral, e ele irá opor um "pessimismo revolucionário" ao otimismo burguês que procura associar progresso técnico e progresso da humanidade ${ }^{11}$. O que a modernidade capitalista estaria entendendo como progresso, para Benjamin, corresponderia na verdade a uma "evolução para a catástrofe", e somente a Revolução poderia interromper esta "evolução" fatídica, que é na verdade uma "involução", uma precipitação que conduziria à barbárie. Estas ideias já aparecem claramente desenvolvidas em uma obra da década de 1920 - Rua de Mão única (19231926) - e Benjamin irá retomá-las também em seus últimos escritos: as Teses sobre o Conceito de História (1940) $)^{12}$.

É preciso chamar atenção para o fato de que esta crítica ao progresso, em Benjamin, não se dirige apenas contra a modernidade capitalista, mas também contra os setores do Materialismo Histórico que ele encara como um "marxismo vulgar", por acreditar que a Revolução seria o resultado final de uma evolução que ocorreria inevitavelmente. Benjamin retoma aqui um alerta que já havia sido proferido décadas antes por Rosa Luxemburgo em "Socialismo ou Barbárie"13, e sustenta que a revolução socialista não é um produto inevitável do desenvolvimento histórico que cedo ou tarde irá acontecer em decorrência do progresso técnico e da dialética entre as "forças de produção" e as "relações de produção". Ao contrário, a Revolução, para ocorrer, teria que se constituir em uma "tomada de decisão" - ela não 
poderia ser senão um acontecimento transversal que interrompe a "marcha para a catástrofe".

O que mais nos interessa neste momento é a leitura do problema historiográfico da "retrodição" que é encaminhada por Benjamin em suas Teses sobre o Conceito de História (1940). Falávamos há pouco da crítica de Benjamin à ideia de que vivemos o único presente possível, decorrente do único passado possível, e que conduz a um futuro igualmente definido sob a ingerência de um tempo linear e ditado pelo progresso. Uma certa História, falseada pelos historiadores a partir da "retrodição", acompanha esta concepção linear e progressista do tempo. Por trás desta historiografia, estende-se uma única metodologia: a História que nos chega através da massa de produtos historiográficos, a maior parte dos quais produzidos a partir da retrodição historiográfica, é uma História que eliminou tudo aquilo que não se encaixava nos projetos que triunfaram. Ela eliminou "centelhas de esperança" que foram importantes no passado, e que seriam igualmente importantes para agir com vistas a um certo futuro ${ }^{14}$. A História, com a sua seleção retroditora, tornou-se um imenso "cortejo triunfal dos vencedores", que carrega em procissão os despojos dos vencidos, muitos dos quais sob a forma de bens culturais. A massa dos historiadores - que Benjamin irá reunir sob o rótulo generalizador de "historicistas" - produz a sua História a partir de uma "empatia com os vencedores", ao fim do qual não se tem mais do que uma história bajulatória. Estes historiadores consideram que a história seguiu o seu curso natural, um curso ditado pelo Progresso, mesmo que com desvios momentâneos e horrores vários. O Progresso desenrola-se naturalmente. Não há mesmo, no limite, necessidade de lutar por um futuro que virá naturalmente, e pode-se entregar-se à "inércia do coração". Assim pensam esses historiadores, que na verdade constituem a ampla maioria, de acordo com as percepções de Benjamin:

Todos os que até hoje venceram participam do cortejo triunfal, em que os dominadores de hoje espezinham os corpos dos que estão prostrados no chão. Os despojos são carregados no cortejo, como de praxe. Esses despojos são o que chamamos de bens culturais. O materialista histórico os contempla com distanciamento. Pois todos os bens culturais que ele vê têm uma origem sobre a qual ele não pode refletir sem horror. Devem sua existência não somente ao esforço dos grandes gênios que os criaram, como à corvéia anônima dos seus contemporâneos. Nunca houve um monumento da cultura que não fosse também um monumento da barbárie. E assim como a cultura não é isenta de barbárie, não o é, tampouco, o processo de transmissão da cultura. Por 
isso, na medida do possível, o materialista histórico se desvia dela. Considera sua tarefa escovar a história a contrapelo (BENJAMIM, tese 7; 2008, p.225)

O historiador, particularmente aquele preocupado em reabrir cada presente como um portal de tomadas de decisão, deveria reformular o seu projeto de historicidade e se converter em um "apanhador de centelhas de esperanças" (pelo menos aqueles historiadores interessados em reverter a eterna tirania dos poderosos). Nesta perspectiva, cada esforço de emancipação e de luta pela libertação, ainda que frustrado à sua época e por menor que tenha sido, deveria ser objeto de interesse deste historiador que toma a seu cargo a rememoração redentora que restitui um sentido para cada voz silenciada no passado. As lutas de hoje, de acordo com Benjamim, permitem iluminar o passado, e as lutas do passado incorporam-se aos combates de hoje, libertando-se das prisões de silêncio que lhes são impostas pela historiografia tradicional dos vencedore ${ }^{15}$. Esta ideia de que o presente ilumina $o$ passado, e este fortalece o presente (LÖWI, 2005, p.61), encontrou no talento poético de Walter Benjamin uma de suas mais belas metáforas:

Assim como as flores dirigem sua corola para o sol, o passado, graças a um misterioso heliotropismo, tenta se dirigir para o sol que se levanta no céu da história (BENJAMIN, tese 4; 2008, p.224).

O Sol, na metáfora de Benjamin, corresponde a cada novo momento, em um presente, no qual se abre uma nova possibilidade de luta, real ou simbólica; as flores representam todas as ações e esforços dos oprimidos do passado e dos heróis que um dia se empenharam em sua libertação; de um ponto de vista mais estritamente metodológico, são também as fontes e discursos de um passado que podem sintonizar com este novo Presente que se ergue no horizonte. Subitamente iluminadas pelo sol de um novo presente, estas flores oferecem-se aos historiadores, que buscam nas fontes históricas as "centelhas de esperança". É aliás notável que Benjamin mencione, nestas lutas de classes que se atualizam através do trabalho historiográfico, e que "agem de longe, do fundo dos tempos", não apenas os combates físicos e concretos, espetaculares e impactantes. Ao lado da "coragem" e da "firmeza", as lutas que vêem do passado também podem se dar através da "astúcia", do "humor", e de outras qualidades espirituais (BENJAMIN, tese $\mathrm{n}^{\circ} 4$; 2008, p.224).

Desta maneira, torna-se legítimo ao historiador, poderíamos acrescentar, não apenas arrancar do passado as batalhas e marchas heróicas, as resistências obstinadas dos indivíduos e das comunidades em revolta, os 
escravos sangrados por seus feitores e os heróis queimados na inquisição, mas também as coisas aparentemente mais simples: um jogral que afronta o rei através de sua poesia, o humorista que combate à sombra de suas anedotas, o artista que imortaliza em imagens a luta ou a opressão, o literato que astuciosamente denuncia as mazelas de sua época, os trabalhadores que se dissolvem no modo de produção, ou mesmo o louco que, ao fugir da realidade que o oprime, neste mesmo instante já a afronta. É este o sentido das palavras registradas por Benjamin na sua terceira tese, quando diz que "nada do que um dia aconteceu pode ser considerado perdido para a história". É também este o sentido mais íntimo da observação de Walter Benjamin de que o historiador não deve "distinguir entre os grandes e os pequenos" (BENJAMIN, tese 3; 2008, p.223). Para a História que a cada novo Presente reapresenta no seu horizonte historiográfico um novo sol, têm igualmente valor tanto o Napoleão que atravessa os gélidos desertos da Rússia, como o beato Antônio Conselheiro, que conduz através do sertão brasileiro a sua massa de desvalidos. Iluminar Joana D’Arc, queimando nas fogueiras da Inquisição, mostra-se uma tarefa de igual valor àquela que se propõe a seguir os passos de uma família de retirantes nordestinos, ou uma pequena caravana de cristãos-novos anônimos que força a sua entrada em uma nova e perigosa realidade. A partir de cada flor que oferece sua corola à nova contemplação historiográfica, e que se deixa colorir de uma nova maneira por esta mesma contemplação, não será a tarefa do historiador conhecer o passado "como ele de fato foi" ${ }^{16}$, mas sim "apropriar-se de uma reminiscência, tal como ela relampeja no momento de um perigo" (BENJAMIN, tese 6; 2008, p.224) ${ }^{17}$.

O papel deste "momento de perigo" ao qual se refere Benjamin é particularmente importante para a sua proposta historiográfica. $\mathrm{O}$ "momento de perigo" é este limiar no qual as apostas podem ser colocadas, este portal através do qual se torna evidente que tudo se encontra aberto a cada instante do devir histórico: somente neste momento o Passado oferece a sua verdadeira imagem, múltipla, instável, provisória, lampejando de liberdade, pois é precisamente neste "instante de perigo" que se dissolve a falsa imagem do progresso ininterrupto. Em nenhum outro momento a história se oferece tão transparente à contemplação de suas várias faces como neste instante de perigo - que não é necessariamente o momento de uma batalha ou de uma fogueira, mas também aquele em que se exerce uma astúcia ou no qual o humor se pronuncia, ou aquele outro momento em que uma negociação se estabelece e que a história se abre para uma decisão. Existe, aliás, uma dialética que se estabelece entre o perigo de hoje e o "instante de perigo" que nos chega através de uma imagem do passado, como uma flor que volta 
sua corola para o sol do presente. Sob a excitação de uma ameaça iminente, no tempo presente, é que se oferece a oportunidade exemplar para que se volte ao passado um olhar crítico, em busca de outros momentos de perigo diante dos quais os homens se mostraram realmente livres para a tomada de decisões ${ }^{18}$.

A bela imagem das flores do passado que se voltam para o sol do presente, "através de um misterioso heliotropismo", também aparece de uma outra maneira na segunda tese de Benjamin sob a forma do "encontro secreto, marcado entre as gerações precedentes e a nossa” (BENJAMIN, tese 2; 2008, p.223) ${ }^{19}$. É este também o sentido do "messianismo" de Walter Benjamin. Para ele, o Messias não é um ser sobrenatural que desce à terra como um miraculoso salvador que vem reger os altissonantes acordes do Juízo Final, mas a própria humanidade oprimida que, através do trabalho do historiador, adquire a possibilidade de redimir os seus heróis e as vítimas da opressão, os inúmeros homens e mulheres que foram condenados à obscuridade e ao silêncio dos inocentes, os que combateram com coragem, astúcia ou humor, e que agora "falam do fundo dos tempos" e recolorem-se através da rememoração orquestrada por um novo sol historiográfico ${ }^{20}$.

Uma das mais emblemáticas passagens das Teses sobre o Conceito de História de Walter Benjamin (1940) refere-se a um certo quadro do pintor Paul Klee, de cuja imagem o filósofo alemão se apropria para seus próprios fins:

Há um quadro de Klee que se chama Angelus Novus. Representa um anjo que parece querer afastar-se de algo que ele encara fixamente. Seus olhos estão escancarados, sua boca dilatada, suas asas abertas. $\mathrm{O}$ anjo da história deve ter este aspecto. Seu rosto está dirigido para o passado. Onde nós vemos uma cadeia de acontecimentos, ele vê uma catástrofe única, que acumula incansavelmente ruína sobre ruína e as dispersa a nossos pés. Ele gostaria de deter-se para acordar os mortos e juntar os fragmentos. Mas uma tempestade sopra do paraíso e prende-o em suas asas com tanta força que ele não pode mais fechá-la. Essa tempestade o impele irresistivelmente para $o$ futuro, ao qual ele vira as costas, enquanto o amontoado de ruínas cresce até o céu. Essa tempestade é o que chamamos progresso (BENJAMIN, tese n. $9 ; 2008$, p.226).

O Angelus Novo de Paul Klee, reinterpretado por Walther Benjamin como um enigma sobre a própria História, tornar-se-ia uma das imagens mais fortes da história intelectual da rejeição à concepção mecanicista de "progresso". A imaginação benjaminiana em torno da pintura de Paul Klee 
parece insinuar que seria uma tarefa urgente 'desconstruir' a noção de progresso - dar a perceber os elementos que introduzem sorrateiramente essa falácia no mundo contemporâneo através de um desvirtuamento da própria historiografia, que termina por fazer da noção de progresso a mais poderosa força a serviço da alienação. Acreditar que o progresso é a norma, postulará Benjamin, pode levar à inação, à acedia (a "inércia do coração") ${ }^{21}$, ao abandono do campo de lutas aos que controlam a História para impor o seu controle sobre a história.

Dar a perceber que a história é um campo de lutas, e que "o estado de exceção em que vivemos é na verdade a regra geral" (BENJAMIN, tese 8 , 2008, p. 226), seria a função deste "historiador combatente" que é idealizado por Benjamin nas suas Teses sobre o Conceito de História - um historiador de novo tipo que deveria tomar a si a tarefa de "escovar a história a contrapelo" (p. 225). Ao reconhecer a história como arena na qual se defrontam forças diversas, tal como já fizera Nietzsche, mas também Marx, Walter Benjamin adere ao compromisso deste último com relação à possibilidade de contribuir para a transformação efetiva do mundo em favor da imensa maioria explorada. Nietzsche tendia a valorizar uma escrita da História que colocasse em relevo os pontos culminantes da humanidade - os grandes homens entre os quais a História poderia construir uma ponte de intercomunicação. Benjamin invocará uma historiografia que possa mostrar aos oprimidos que o processo histórico até hoje vivido pela humanidade tem constituído um grande "estado de exceção", no qual se perpetuam horrores e se exigem sacrifícios das classes desfavorecidas. O Fascismo dos anos 1940, que contextualiza esta obra de Benjamin, nada mais seria do que um momento no qual este "estado de exceção" ficara mais claro ${ }^{22}$.

De fato, ao fazer a reflexão sobre os rumos da história de sua época ser atravessada por sua radical crítica à noção mecanicista de "progresso", Benjamin irá questionar as interpretações liberais, ou mesmo vinculadas a setores do Materialismo Histórico, de acordo com as quais a emergência do Fascismo teria correspondido a uma "ruptura do progresso", a uma explosão de irracionalidade, a um absurdo desvio da história européia que interrompera a marcha do progresso. Ele se pergunta se o Fascismo não é precisamente a consequência natural do desenvolvimento da sociedade burguesa, ou mesmo, se a própria história deste desenvolvimento das sociedades burguesas não seria ela mesma uma sucessão de estados de exceção da qual o Fascismo não seria mais do que uma expressão mais intensa, avivada pela possibilidade de dirigir o próprio "progresso tecnológico" e o desenvolvimento as comunicações para resultados extremamente destrutivos ${ }^{23}$. 
Este conjunto de reflexões de Walter Benjamin sobre a emergência dos totalitarismos é singular e único em sua época. À parte os horrores do Fascismo, o filósofo alemão considera que não muito menos nocivo seria o convite à inação implicado naqueles outros tempos aparentemente mais amenos, e que por isto mesmo melhor conseguem esconder a eterna catástrofe que se abate sobre os trabalhadores e oprimidos da história. A ideologia do progresso, dirá Benjamin também aqui, distorce o significado que a História poderia oferecer aos oprimidos na sua árdua luta por um mundo efetivamente melhor para todos, e por isto a crítica da ideia de progresso a partir de suas evidências deveria ser colocada como a principal tarefa dos historiadores solidários com um futuro que não quisesse perpetuar a catástrofe ${ }^{24}$. A crítica desta ideologia, na verdade, deveria vir acompanhada da própria crítica da imagem de tempo que a ampara:

A ideia de um progresso da humanidade na história é inseparável da ideia de sua marcha no interior de um tempo vazio e homogêneo. A crítica da ideia de progresso tem como pressuposto a crítica da ideia desta marcha (BENJAMIN, tese n.13; 2008, p. 229).

Romper a inércia através de uma correta compreensão sobre como vem funcionando a história seria fundamental para que os seres humanos retomassem a perspectiva de uma história que se abre diuturnamente à tomada de decisões (uma perspectiva que já vimos ter sido também invocada por Nietzsche). Somente ao compreender e assumir seu papel de ator histórico capaz de interferir a cada instante nos destinos do mundo, cada homem poderia vislumbrar a História como "objeto de uma construção cujo lugar não é o tempo homogêneo e vazio, mas um tempo saturado de 'agoras"' (BENJAMIN, tese n.14; 2008, p. 229) ${ }^{25}$.

Se Benjamin desfecha algumas de suas mais viscerais críticas contra os historicistas que vinham atrelando o seu trabalho ao sistema de poderes constituídos e ao capital dominante, devemos compreender, por outro lado, que a retrodição a-crítica, como tendência ou prática de fazer a história, não seria apanágio dos historiadores cujo trabalho termina por apoiar os poderes dominantes: de fato, também os historiadores solidários com as lutas sociais frequentemente se poderiam ver-se enredados pela prática a-crítica da retrodição. Escapar à tendência da 'retrodição historiográfica' não seria tão fácil, mesmo porque este modo de ver a história estaria sempre surgindo espontaneamente da própria prática historiográfica, ainda que fosse a mais honesta e desinteressada, como um modus operandi não questionado. Assim, 
o grande pecado historiográfico, oculto na prática quase automática da retrodição, e da qual poucos estariam se dando conta mesmo nos dias de hoje, seria o da "Linearidade". Vejamos as palavras de Joseph Fontana (n.1931), um historiador que escreve a partir das últimas décadas do século XX, a partir de uma perspectiva integralmente associada ao Materialismo Histórico, mas que sempre se empenhou em evitar qualquer forma de determinismo ingênuo, procurando pensar e repensar constantemente as possibilidades de ultrapassar tanto os "becos-sem-saída" da historiografia pós-moderna como os aparentemente insolúveis dilemas do marxismo no tempo presente:

Abandonar a Linearidade ajudar-nos-á a superar não só o eurocentrismo, mas também o determinismo. Ao propor as formas de desenvolvimento econômico e social como o ponto culminante do progresso - como o único ponto de chegada possível, apesar de suas deficiências e de sua irracionalidade - escolhemos, dentre todas as possibilidades abertas aos homens do passado, somente as que conduziram ao presente e menosprezamos alternativas que alguns propuseram, ou tentaram, sem nos determos em explorar as possibilidades de futuro que continham (FONTANA, 2004, p. 478).

O padrão específico de fazer historiográfico ao qual se refere Josep Fontana - imaginar de antemão um ponto de chegada (que neste caso específico é o nosso próprio Presente) e a partir daí ir selecionando apenas o que interessa do vasto material empírico que a história nos oferece - corresponderia na verdade a uma variação de um modo de pensar e de uma postura metodológica mais amplos, já de muito arraigada na prática historiográfica ocidental. Em seu célebre ensaio "As Peculiaridades dos Ingleses", incluído pela primeira vez na coletânea A Miséria da Teoria (1978), Edward Thompson já ressaltava que "nada é mais fácil do que levar um modelo até o prolífero desenvolvimento da realidade, dele selecionando apenas as evidências que estiverem em conformidade com os princípios seletivos" (THOMPSON, 2001, p.154). No caso da grande tendência ocidental a construir a história de acordo com a teleologia reversa, essa mesma prática é construída sob o signo da Linearidade, do enquadramento de tudo em uma história da qual já se sabe de antemão o final, e do silenciamento de todas as vozes que atrapalham o enredo coerente, construído à maneira do romance tradicional.

A contraproposta a este fazer historiográfico que surge quase naturalmente em nossa cultura já teria sido aventada por alguns historiadores, em falas isoladas e que foram pouco percebidas. Fontana cita o historiador inglês 
Christopher Hill (1912-2003), que teria comentado que valeria a pena "adentrarmos imaginariamente o passado no tempo em que as diversas opções pareciam abertas" (FONTANA, 2004, p.479) ${ }^{26}$. Christopher Hill, aliás, é um dos historiadores que de algum modo trabalhou, desde as últimas décadas do século XX, com esta perspectiva complexa. Um grande número destas alternativas, descontinuidades e bifurcações não-percorridas é nos trazido pela leitura de seu livro O Mundo de Ponta-Cabeça (1972), um ensaio sobre os reformistas radicais do século XVII que foram engolidos pela Reforma Oficial que passou a vigorar na Inglaterra e se adaptou ao sistema. O que Hill procurou fazer em seus estudos da reforma radical da Inglaterra seiscentista foi precisamente ultrapassar o formato linear da historiografia tradicional, dando voz aos movimentos que ficaram de fora desta História oficial.

Outro historiador a se preocupar com os inconvenientes da prática da "retrodição" foi Renajit Guha - um historiador sul asiático que tem desempenhado um papel importante nos chamados "estudos de grupos subalternos". Guha discute o problema da retrodição historiográfica a partir de um interessante exemplo que mostra que a manipulação historiográfica pode ser mesmo involuntária, por estar visceralmente inscrita no próprio 'padrão de escrever a História' seguido pelo historiador. Ele discute algumas situações elucidativas no ensaio History at the Limit of World-History (2002), e também no artigo The Small voice of History, publicado na série dos Estudos Subalternos em 1996.

O principal alvo de críticas de Guha é aquele a que este historiador indiano se refere como um padrão "estatista" de historiografia - e que termina por se inscrever nos esquemas interpretativos que, voluntária ou involuntariamente, terminam por remeter às estruturas estatais ou às diversas formas de estruturação do poder social típicas de nosso tempo. Os exemplos mais abundantes já são velhos conhecidos desde o século XIX, e coincidem com as próprias realidades nacionais que ainda inscrevem muito da historiografia do nosso tempo. Muito da velha, e mesmo da nova História Política, mas também de outras modalidades historiográficas, acaba por legitimar retrospectivamente as estruturas estatais da época em que escreve o historiador, conforme a sugere Guha. Na época das grandes sínteses historicistas financiadas pelos estados-nacionais europeus isso era bastante explícito, e era até mesmo assumido profissionalmente por historiadores como Ranke, Droysen e tantos outros. Mas mesmo na historiografia não atrelada diretamente a uma instituição estatal, pode-se dar que a estrutura estatal se veja confirmada ou mesmo legitimada através do próprio padrão linear de escrita historiográfica que ainda vigora em nosso tempo. 
Guha fornece exemplos sobre isto, e não apenas relacionados ao poder estatal institucionalizado, mas também a muitas outras instâncias políticas, inclusive aquelas que atuam ativamente contra o poder estatal vigente. Pensemos em um Partido Político de esquerda que propõe a escritura de sua própria história. A narrativa resultante desta história poderá se valer de inúmeros materiais, bem como se apropriar de diversificadas vozes sociais, mas ao final da escrita historiográfica tem-se uma narrativa coerente, que eliminou tudo aquilo que não estaria conformado à narrativa de sua gloriosa luta pelo poder ou de sua tenaz resistência contra os poderes que lhe oprimem. O exemplo clássico desenvolvido por Guha, e que é retomado posteriormente por Joseph Fontana em seu livro História dos Homens (2004, p.482), refere-se a um relato historiográfico sobre a frustrada revolta hindu de Telangana, liderada pelo Partido Comunista Indiano entre 1946 e 1951. Trata-se, neste caso, de um relato que se acha inteiramente subordinado à história (ainda não vitoriosa) da construção de um poder alternativo: o do Partido Comunista Indiano. A Revolta de Telangana dera-se na HistóriaEfetiva a partir da combinação das ações de diversos grupos com reivindicações próprias, inclusive um setor importante de mulheres politizadas que apoiaram a revolta tendo em vista as suas próprias reivindicações. No relato escrito pelos historiadores ligados ao Partido Comunista Indiano, continua Guha, elas terminam por ser reduzidas a simples "colaboradoras do programa dos dirigentes do partido" (FONTANA, 2004, p.482). Por mais que os autores do relato tenham simpatia por estas mulheres rebeladas, e esta é uma observação acrescentada por Josep Fontana, tudo o que não se faz é "escutar o que elas diziam, já que isto destruiria o estatismo dominante no relato" (FONTANA, 2004, p. 482).

Ou seja, o que vemos a partir deste magistral exemplo abordado por Renajit Guha, é que um autor historiográfico encontra-se habitualmente preso à estrutura de construção de um texto unilinear e coerente que converge para um enredo único. No decorrer da sua operação historiográfica, ele seleciona, dentre os fatos e elementos que entrarão na composição do relato, apenas os que interessarão a este enredo. De igual maneira, os depoimentos e discursos das diversas vozes sociais investigadas são desconstruídos para serem integrados a uma trama. A reivindicação específica das mulheres que atuaram no movimento, singularizadas por sua luta contra as desigualdades de gênero, são descontextualizadas desta inscrição mais importante de seus atos e de seus discursos, e recontextualizadas pela história de um partido político. Suas reivindicações e ações perdem a singularidade, são convertidas em peças que se encaixam em um quebra-cabeças construído pela história 
de um partido político em sua luta, ela mesma alternativa, contra um poder estatal vigente. Ao fim de tudo, o relato encaixa-se como todos os demais - a favor ou contra - em um determinado padrão estatista. Este padrão deformou a natureza dos discursos que foram reapropriados pelo relato - é isto o que nos sugere Guha no artigo The small voice of history (1996).

O que nos propõe Guha como alternativa para o problema tão bem levantado por ele mesmo? O historiador indiano considera, em primeiro lugar, que pouco acrescentaria ao problema levantado a substituição de um relato unilinear por um outro. Um relato feminista das lutas sociais encaminhadas pela Revolta de Telangana, embora deslocando os atores sociais e ressignificando sua posição apenas confirmaria os mesmos procedimentos historiográficos da história partidária antes descrita, pois também eliminaria outros dados e fatos que não interessassem, terminando por ajustar todos os discursos a uma nova finalidade: a de denunciar a opressão do gênero feminino. A sugestão de Guha, em vista disto, aponta para a construção de um relato polifônico. Trata-se de romper a unilinearidade e de complicar o argumento (FONTANA, 2004, p.483). O historiador indiano sustenta que ainda não sabe exatamente como isto se dará, mas que muito provavelmente estariam por ocorrer ainda, em um futuro não muito distante, importantes modificações nos modos de fazer a história, e isso como única maneira de romper o padrão de linearidade e coerência que estaria tão arraigado na própria escrita historiográfica.

A proposta seria desenvolver um tipo de "escrita polifônica", na qual diversas vozes se manifestassem em pé de igualdade do ponto de vista do direito a um espaço discursivo Este arranjo polifônico, contudo, deveria primar por corrigir problemas de "assimetria" que sempre aparecem na prática discursiva. Isto é, deveria ser evitado que determinada voz adquirisse um peso maior e uma posição discursiva privilegiada em relação às demais. Como se daria isto? Certamente que o desenvolvimento de uma escrita polifônica, e outros padrões para além da escrita historiográfica linear, teria de ser aprendido pelos historiadores em formação, o que dificilmente poderia se der sem a inclusão no currículo de ensino universitário de disciplinas voltadas para a própria escritura da História, em sentido literal. O historiador, em seus anos de formação, precisaria ser também treinado para se tornar artista - e isto nos remete mais uma vez às reflexões pioneiras desenvolvidas por Friedrich Nietzsche na segunda metade do século XIX.

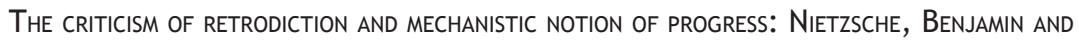
GUHA 
Aвstract: This article aims to reflect about contemporary critic to the mechanic notion of "progress" and, more specifically, about the methodological problem of the historiography "retro diction". It is discussed initially the question of the finalism in the teleological approach of History, and, in the sequence, it is examined the really question that involves this and other problems presented in the construction of the historiography explanations: the retro diction. After theorymethodological clarifications about the question, with historiography examples, they are developed commentaries about some authors that have elaborated perceptions of this problem, among whose Friedrich Nietzsche, Walther Benjamin, Ramjet Gotha, Christopher Hill e Joseph Fontana.

KEYwORDs: retrodiction, teleology, historiography, Nietzsche, Walther Benjamin.

\section{NOTAS}

1 Em Manifesto Comunista (1848), Marx registra as seguintes palavras: "A burguesia produz, sobretudo, seus próprios coveiros. Sua queda e a vitória do proletariado são igualmente inevitáveis" (MARX, 1984, p.375).

2 A primeira lição do Curso de Filosofia Positiva apresenta a célebre "lei dos três estados". Para uma síntese da teoria dos três estágios, ver o Catecismo Positivista (1934, p. 479). Um exemplo de afirmação teleológica em Comte pode ser trazido pelo seguinte treco de Discurso sobre o Espírito Positivo (1985, p.103-104): “Numa palavra, tem por objetivo geral facilitar o advento do novo poder espiritual que o positivismo representa como único apropriado para levar a termo a revolução, pela fundação direta do regime final para o qual tende hoje a elite da humanidade".

3 Historicismo está sendo empregado aqui como designação de um paradigma historiográfico, e não como sinônimo de história científica. Referimo-nos ao paradigma introduzido pela Escola Histórica Alemã nas primeiras décadas do século XIX.

4 A frase de que o século XIX é o século da história foi proferida pela primeira vez pelo historiador oitocentista Thierry (1827).

5 Rigorosamente falando, fazer uma "retrodição" é presumir uma causa para um evento; é estender um olhar para trás buscando a sua origem ou algum elo que está faltando em determinada cadeia causal explicativa.

6 Também Johann Gustav Droysen já alertara em seu Historik (1858) para o problema da retrodição, embora sem lhe dar este nome e não lhe dispensando um maior aprofundamento. Em certa passagem do seu Manual de História, ele critica a linearidade historiográfica e a busca ingênua de causas e efeitos, em uma passagem que também apresenta uma crítica à ambição positivista de encontrar as leis de história: "A pesquisa histórica não tem por ambição explicar, ou seja, não pretende deduzir do anterior o posterior; os fenômenos necessariamente como 
efeitos de evoluções e leis que os regem. / Se a necessidade lógica do posterior residisse no anterior, então existiria, ao invés do mundo ético, um análogo de matéria eterna e da transformação dos materiais. / Se a vida histórica fosse somente uma nova geração do que é sempre igual, então ela seria sem liberdade e sem responsabilidade, desprovida de conteúdo ético; ela seria apenas de natureza orgânica" (DROYSEN, 2009, p.54).

7 "Quer dizer, não deve explicá-las somente pelo conhecido desenlace de uma situação, como não deve fazê-lo tampouco pelas 'intenções dos atores'. A explicação fundamenta-se na dialética precisa entre ambas as coisas" (ARÓSTEGUI, 2006, p.354).

8 As críticas à noção de progresso e à formatação linear da História já aparecem nas primeiras obras de Walter Benjamin. Iremos encontrá-las desde em seus textos da segunda década do século XX, como "A vida dos estudantes" (1915), até os últimos textos, como as "Teses sobre o Conceito de História" (1940) e alguns dos textos incluídos em Passagens (1927-1940). / Lembramos também que a crítica à noção de "progresso" na história, herdada do iluminismo, está contemplada também na obra de diversos outros autores do século XX. Podemos citar o filósofo romeno Emil Cioran (1911-1995), com suas obras Breviário da Decomposição (1949) e História e Utopia (1960), e o filósofo italiano Giuseppe Rensi (1871-1941), com o ensaio A Filosofia do Absurdo (1937). Neste último autor, é radical a rejeição da idéia de um sentido da história, que o filósofo compara a um chão incandescente que tem de ser dolorosamente percorrido a esmo pelos seres humanos na sua precipitação para o futuro. Já Cioran, em seu Breviário da Decomposição (1949), insistirá na idéia de que a única vantagem do homem contemporâneo sobre seus ancestrais pré-histórico é a de gerir melhor o seu "capital de infortúnio", de modo a "melhor organizar o seu desastre" (p.173174). Sobre Cioran, ver PECORARO, 2009.

9 Walter Benjamin conhecia bem o texto de Nietzsche sobre "Sobre a utilidade e os inconvenientes da história para a vida". Ele o cita implicitamente em diversas passagens de suas "Teses sobre o Conceito de História", e transcreve uma passagem deste texto de Nietzsche como epígrafe para a sua "Tese n ${ }^{\circ} 11^{\text {". }}$

10 A esquerda alemã, durante as primeiras décadas do século XX, estava bastante dividida, o que inclusive é apontado como um dos fatores que favoreceram a ascensão do Nazismo no quadro político da Alemanha após a Primeira Guerra. Em 1918 o Partido Político Alemão (KPD), havia se destacado do Partido Social-Democrata Alemão (SPD). Depois, ocorreriam novas divisões no interior do primeiro (1920: formação do KAPD, Partido Comunista Operário Alemão). A influência do bolchevismo soviético sobre parte da esquerda alemã entra como outro fator complicador, particularmente com a ascensão de Stalin. Benjamin mostrará mais simpatia pela dissidência trotskista, mas conservará sempre um pensamento político independente. Este complexo quadro político também faz parte do contexto em que Benjamin escreveu a maior parte de suas obras. 
11 O "pessimismo revolucionário" proposto por Benjamin guarda sua distância em relação aos modelos românticos de pessimismo, sejam os pessimismo resignados e alienantes, sejam os pessimismos da evasão; tampouco se identificará com outros modelos de pessimismo de sua própria época, como o do Declínio do Ocidente de Oswald Spengler (1920). O modelo de pessimismo revolucionário aparecerá em diversos textos de Benjamin, para além das Teses sobre o Conceito de História, tal como no ensaio intitulado "O Surrealismo" (1929, p.312).

12 Em um dos comentários de Rua de Mão Única, intitulado "alarme de incêndio", Benjamin chama atenção para os perigos do progresso técnico desalinhado dos progressos da justiça social e dos valores éticos: "[...] se a eliminação da burguesia não estiver efetivada, até um momento quase calculável do desenvolvimento econômico e técnico (a inflação e a guerra de gases o assinalam), tudo está perdido. Antes que a centelha chegue à dinamite, é preciso que o pavio que queima seja cortado" (BENJAMIN, 1995, p.45-46).

13 Sobre os pontos de contacto entre as posições de Walter Benjamin e esta obra escrita por Rosa Luxemburgo, ver os comentários de Michael LÖWI em Walter Benjamin: aviso de incêndio - uma leitura das reses "sobre o conceito de história". (2005, p.23).

14 "O dom de despertar no passado as centelhas de esperança é privilégio exclusivo do historiador convencido de que também os mortos não estarão em segurança se o inimigo vencer. E esse inimigo não tem cessado de vencer" (BENJAMIN, tese 6; 2008, p.224).

15 Exata idéia de que o silêncio dos vencidos possa ser redimido pelos historiadores, tal como observa Michael Löwi em seu ensaio sobre as "Teses sobre o Conceito de História" de Walter Benjamin, é similar às propostas de Max Horkheimer (1895-1973) - outro dos filósofos ligados à Escola de Frankfurt - particularmente no texto Crépuscules: notes em Allemagne (1926-1931). Depois de mencionar os oprimidos da história e seu eterno "sonho de libertação", Horkheimer ressalta: "é doloroso ser desconhecido e morrer na obscuridade. Clarear essa obscuridade, essa é a honra da pesquisa histórica" (HORKHEIMER, 1994, p.159).

16 Ao citar esta frase em sua sexta tese, Benjamin está se referindo ao célebre dito de Leopold von Ranke, que pretendia contar os fatos tal como eles se sucederam. A esta altura, na primeira etapa da fundação do paradigma Historicista, alguns elementos positivistas ainda o perpassam, particularmente no que se refere à pretensão de neutralidade por parte do sujeito que produz o conhecimento histórico. Obviamente que, à época do próprio Walter Benjamin, o Historicismo já tinha desenvolvido em maior profundidade os seus desdobramentos relativistas.

17 Segue Benjamin, na mesma sequência, com as seguintes palavras: "Cabe ao materialismo histórico fixar uma imagem do passado, como ela se apresenta, no momento do perigo, ao sujeito histórico, sem que ele tenha consciência disso" (BENJAMIN, tese 6; 2008, p.224). 
18 Michael Löwy, em sua excelente análise sobre as "Teses sobre o Conceito de História”, entretece algumas considerações importantes a respeito deste aspecto: "O perigo de uma derrota atual aguça a sensibilidade pelas anteriores, suscita o interesse dos vencidos pelo combate, estimula um olhar crítico voltado pela história. Benjamin talvez pense em sua própria situação: não foi o perigo iminente em que ele se encontrava entre 1939 e 1940 - prisão, internação nos campos de concentração, entrega pelas autoridades vichystas à Gestapo - que provocou a visão singular, única mesmo, do passado que emana das "Teses sobre o Conceito de História"?” (LÖWY, 2005, p.65). O Nazismo, de fato, e a perseguição que levou Benjamin à morte em 1940, no mesmo ano em que escrevia as suas "Teses sobre o Conceito de História”, constituem o grande contexto deste singular manuscrito. É em um momento de extremo perigo que Benjamin o redige.

19 Prossegue Benjamin na mesma sequência: "Alguém na terra esta à nossa espera. Nesse caso, como a cada geração, foi-nos dada uma frágil força messiânica para a qual o passado dirige um apelo. Esse apelo não pode ser rejeitado impunemente. O materialista histórico sabe disso" (BENJAMIN, tese 2; 2008, p.223).

20 "Pois o Messias não vem apenas como salvador, mas também como o vencedor do Anticristo. O dom de despertar do passado as centelhas de esperança é privilégio exclusivo do historiador convencido de que também os mortos não estarão em segurança se o inimigo vencer. E esse inimigo não cessa de vencer" (BENJAMIN, tese 6, 2008, p.224-225). Essa passagem, e a menção à imagem do "Anticristo", pode ser particularmente compreendida à luz dos enfrentamentos contra o Nazismo. Por outro lado, se o Anticristo pode ser mais diretamente referido ao próprio Nazismo, com relação ao contexto mais imediato, também é uma imagem que se refere às classes dominantes, o que ficará ainda mais claro nas teses seguintes. De todo modo, não foram raras, na época do $\mathrm{II}^{\circ}$ Reich, as interpretações que ressignificaram o Nazismo como o Anticristo Moderno.

21 A "acedia", expressão que aparece na sétima tese, pode ser compreendida como o sentimento melancólico que surge da sensação de impotência diante da fatalidade, e que pode conduzir à submissão em relação às forças que regem a realidade social. Michel Löwy, em sua análise das "Teses sobre o Conceito de História", vai encontrar a mesma idéia em uma obra anterior de Walter Benjamin: a Origem do Drama Barroco Alemão (1925). Ver LÖWI, 2005, p.71.

22 Benjamin escreve estas “Teses sobre o Conceito de História” em 1940, em pleno período de luta contra o Nazismo. O momento é, inclusive, particularmente decepcionante para alguns setores mais críticos dos pensadores e políticos ligados ao Materialismo Histórico, pois A União Socialista das Repúblicas Soviéticas, através de Stalin, acabara de assinar um pacto de não-agressão com a Alemanha Nazista de Hitler (o pacto "Molotov-Ribbentrop"). De igual maneira, certos encaminhamentos da social-democracia alemã, propondo uma espécie de "evolucionismo social" e refreando a ação direta e o projeto de trabalhar com uma maior conscientização do proletariado, teriam contribuído para a ascensão 
do Nazismo, de modo que não apenas as posições stalinistas, como também as posições da social-democracia alemã são criticadas por Benjamin nas “Teses”. A grande crítica, de todo modo, é ao sistema capitalista e à ilusão de progresso consolidada na sociedade burguesa. Apesar da tenaz crítica às atrocidades fascistas, Benjamin preocupa-se em demonstrar a ligação entre o Fascismo e a modernidade capitalista, bem como situá-lo em uma longa linha de opressões e dominações de classe que constituem a própria história européia.

23 A sutileza das considerações de Walter Benjamin está em dar a perceber que, assim que o Fascismo fosse vencido, nada mudaria tanto a não ser na forma e na intensidade, pois a história seguiria sendo a imposição de sistemas de opressão acobertados pela ilusão do progresso. Diz a "tese n8”: "A tradição dos oprimidos nos ensina que o 'estado de exceção’ em que vivemos é a regra geral. Precisamos construir um conceito de história que corresponda a esta verdade. Nesse momento, percebemos que nossa tarefa é originar um verdadeiro estado de exceção; com isso, nossa posição ficará mais forte na luta contra o fascismo. Este se beneficia da circunstância de que seus adversários o enfrentam em nome do progresso, considerado como uma norma histórica. O assombro com o fato de que os episódios que vivemos no século XX 'ainda' sejam possíveis não é um assombro filosófico. Ele não gera conhecimento, a não ser o conhecimento de que a concepção de história da qual emana semelhante assombro é insustentável” (BENJAMIN, tese $\mathrm{n}^{\circ} 8 ; 2008$, p.226). Desta forma, Benjamin se insurge contra a percepção ingênua do Fascismo como desvio ou como aberração, demonstrando que sua eclosão está perfeitamente atrelada à história européia e aos desenvolvimentos da modernidade. Desconstrói, desta maneira, a tradicional pergunta: "Como o Nazismo foi possível ainda nos dias de hoje?", formulada por aqueles que não concebem que o "progresso" tecnológico seja compatível com a barbárie e os retrocessos sociais, e procura mostrar que, ao contrário, p Fascismo fora precisamente um desdobramento daquilo que tem sido a história da modernidade ocidental até chegar aos dias de hoje.

24 Benjamin pontuará na tese $n^{\circ} 13$ que seria preciso combater a idéia de progresso em três aspectos interligados: (1) desmistificar a confusão de que o progresso "das capacidades e conhecimentos" corresponde a um concomitante progresso da humanidade em si mesma; (2) desmentir a idéia de que o progresso pode ser "um processo sem limites"; (3) desfazer a idéia de que o progresso seria "um processo essencialmente automático, percorrendo, irresistível, uma trajetória em flecha ou espiral" (BENJAMIN, tese ${ }^{\circ} 13 ; 2008$, p.229).

25 Benjamin segue mostrando um exemplo de como o Passado pode ser retomado pelos historiadores e outros agentes históricos de modo a alimentar o Presente e favorecer o reencaminhamento de um futuro: “a Roma antiga era para Robespierre um passado carregado de 'agoras', que ele fez explodir num continuum de história. A Revolução Francesa se via como uma Roma ressurecta. Ela citava a Roma antiga como a moda cita um vestuário antigo. A moda tem um faro para o atual, onde 
quer que esteja na folhagem do antigamente. Ele é um salto de tigre em direção ao passado. Somente, ele se dá duma arena comandada pela classe dominante. O mesmo salto, sob o livre céu da história, é o salto dialético da Revolução como o concebeu Marx" (BENJAMIN, tese ${ }^{\circ}$ 14; 2008, p.229-230). Mais adiante Benjamin dirá: "A consciência de fazer explodir o continuum da história é própria às classes revolucionárias no momento da ação" (tese n.15; 2008, p.230).

26 A obra citada por Fontana é Some intellectual consequences of the English revolution (HILL, 1980. p. 33).

\section{REFERÊNCIAS}

ARÓSTEGUI, Julio. A Pesquisa Histórica: teoria e método. Bauru: Edusc, 2006 [original: 1995].

BENJAMIN, Walter. A Vida dos Estudantes. In: . Reflexões sobre a criança, o brinquedo e a educação. São Paulo: Duas Cidades, 2002 [original: 1915].

BENJAMIN, Walter. O surrealismo: o mais recente instantâneo da inteligência européia. São Paulo: Abril Cultural, 1975 [original: 1929]. (Os Pensadores, v. XLVIII) BENJAMIN, Walter. Teses sobre o conceito o História. In: Walter Benjamin: obras escolhidas - magia e técnica; arte e política. São Paulo: Brasiliense, 2008. p. 222-231 [original: 1940].

BENJAMIN, Walter. Passagens. Belo Horizonte: Editora da UFMG; São Paulo: IMEP, 2006 [original: 1927-1940].

BENJAMIN, Walter. Walter Benjamin: obras escolhidas: rua de Mão única. São Paulo: Brasiliense, 1995 [original: 1923-1926].

BLOCH, Marc. Apologia da História. Rio de Janeiro: J. Zahar, 2001 [original publicado: 1949, póstumo] [original de produção do texto: 1941-1942].

CIORAN, Emir. Breviário da Decomposição. Rio de Janeiro: Rocco, 1989 [original: 1949]

CIORAN, Emir. História e Utopia. Rio de Janeiro: Rocco, 1994 [original: 1961].

COMTE, Auguste. Catecismo Positivista. São Paulo: Igreja Positivista, 1934.

COMTE, Auguste. Discurso sobre o Espírito Positivo. São Paulo: Escala, 1985.

COMTE, Augusto. Cours de philosophie positive. Paris: Classique Garnier, 1969 [originais : 1830-1842].

DOSSE, François. L'histoire em miettes - des Annales à La Nouvelle Historie. Paris: La Découverte, 1987 [A História em Migalhas. São Paulo: Ensaio, 1994]

DROYSEN, J. Gustav. Historik: Vorlesungen über Enzyklopädie und Methodologie der Geschichte. In: LEYH, Peter (Org.). Stuttgart: Fromann-Holzboog, 1977 [em português: Manual de Teoria da História. Petrópolis: Vozes, 2009 [original: 1858].

FONTANA, Josep. A História dos Homens. Bauru: Edusc, 2004 [original: 2000]. FOURIER, Charles. Theorie des quatre mouvements. In: . Ouevres Completes. Paris: Antropos, 1966-1968. 
GUHA, Ranajit. Elementary aspects of peasant insurgency in colonial India. Delhi: Oxford Um. Press, 1993.

GUHA, Ranajit. History at the Limit of World-History. Columbia: Columbia University Press 2002.

GUHA, Ranajit. The Small voice of History. Estudos Subalternos. Delhi: Oxford University Press, 1996.

HEGEL, Friedrich. Filosofia da História. Brasília: Ed. da UnB, 2008 [original: 1830]. HILL, Christopher, Some intellectual consequences of the English revolution. Madisson: The University of Wisconsin Press, 1980.

HILL, Christopher. O Mundo de Ponta-Cabeça. São Paulo: Companhia das Letras, 1987 [original: 1972].

HORKHEIMER, Max. Crépuscules: notes em Allemagne. Paris: Payot, 1994 [original: 1926-1931].

KANT, Immanuel. Idéia de uma História Universal de um Ponto de Vista Cosmopolita. São Paulo: Brasiliense, 1986 [original: 1784]

KOSELLECK, Reinhart. Futuro Passado: contribuição à semântica dos tempos históricos. Rio de Janeiro: Contraponto, 2006 [original: 1979].

LANGLOIS, Charles Victor; SEIGNOBOS, Charles. Introdução aos Estudos Históricos. São Paulo: Editora Renascença, 1944 [original: Introduction aux Études Historiques, Paris: Hachette, 1898].

LEIBINIZ. De rerum originatione radicali. In: E. Erdmann, 1840. Opera Philosophica. Berlim: J.

LOTZE, Rudolf Hermann. Mikrokosmos. Ideen Zur Naturgeschichte Und Geschichte Der Menschheit. Leipzig: Hirzel, 1864.

LOWY, Michael. Uma leitura das 'teses sobre o conceito de história' de Walter Benjamin. In: . Walter Benjamin: aviso de incêndio - uma leitura das teses 'sobre o conceito de história'. São Paulo: Boitempo, 2005. p. 33-159.

MARX, Karl. Manifesto do Partido Comunista. In: . Marx Engels. São Paulo: Ática, 1982-b. p.365-375.

MARX, Karl. Prefácio para a Contribuição à Crítica da Economia Política. In: Marx Engels. São Paulo: Ática, 1982b. p. 231-235.

NIETZSCHE, Friedrich. Fragmentos Póstumos. 1884-85 [incluído em Escritos sobre a História. São Paulo: Loyola, 2005].

NIETZSCHE, Friedrich. Sobre a utilidade e desvantagens da História para a Vida, 1873 [incluído em Escritos sobre a História. São Paulo: Loyola, 2005] [original: 1873; publicado em 1874].

NISBET, Robert. História da idéia de Progresso. Brasília: Ed. da UnB, 1985.

PECORARO, Rossano. Cioran: a filosofia em chamas. Porto Alegre: EDUPUCRS, 2004.

PINEL, Philippe. Traité médico-philosophique sur l'aliénation mentale ou la manie. Paris: Richard, Caille \& Ravier, 1801. 
RENSI, Giuseppe. Frammenti di una filosofia del dolore e dellerrore, del male e della morte. Modena: Guanda, 1937.

SCHOPENHAUER, Arthur. O Mundo como Vontade de Representação. São Paulo: Edunesp, 2005, SIMIAND, F. Méthode historique et science sociale. Annales ESC., n. 1, jan./fev. 1960.

SPENGLER, Oswald. The Decline of the West. Munich: Beck, 1920.

THIERRY, Augustin. Lettres sur le histoire de France. Paris: Le Courrier Français, 1820.

THOMPSON, Edward. As Peculiaridades dos Ingleses. In: A Miséria da Teoria. Monthly Review Press, 1978 (republicado em As Peculiaridades dos Ingleses. Campinas: Ed. da Unicamp, 2001) 